\title{
Research of Ground Waters and their Impacts in Drinking Water, in Some Villages of the Shala Region
}

\section{Dobroshi Florent ${ }^{1}$, Mazrreku Armela2*, Dobroshi Krenar ${ }^{3}$, Behrami Aziz ${ }^{1}$, Malollari Ilirjan ${ }^{4}$}

\author{
1*University of Mitrovica "Is a Boletini, Mitrovica, Kosovo \\ ${ }^{2}$ University "Aleksander Xhuvani", Elbasan, Albania \\ ${ }^{3}$ College of Medical Sciences ,Rezonanca, Prishtinë, Kosovo \\ ${ }^{4}$ Department of Industrial Chemistry, University of Tirana, Albania \\ * Corresponding Author
}

\begin{abstract}
A large number of natural processes and various anthropogenic activities affect the biological, chemical and physical characteristics of the waters, thus altering the normal values of physico-chemical and bacteriological parameters which followed with the change of its quality.Among the activities that influence the change in water quality are: agricultural activities, industrial activities, mining, waste disposal, urbanization and climate change. Through the development of various industrial activities comes the discharge of various waste during water processes such as: heavy metals, various solvents, toxic sludges and many waste of various kinds.

Kosovo has limited water resources either of surface waters or of groundwater, so their rational protection and use is vital for a sustainable economic development of the country. Most of Kosovo's rivers are seasonal rivers that mostly depend on atmospheric precipitation. Village waters in the Shala region in Mitrovica's hydrographic network represent a country's wealth, but the quality of these waters is not satisfactory.

First of all, the environmental impact of industrial wastes, industrial plants, mining landfills, agricultural landfills, etc. should be highlighted. The study consists of physicochemical, bacteriological analysis and determination of heavy metals in underground waters in some villages in the region of Shala (Zhazhë, Maxherë, Boletin, Stantërg, Zjaqë and Vllahi).Physico-chemical and bacteriological analyzes were conducted at the National Institute of Public Health in Mitrovica, whereas the determination of metals was done at the Mining Laboratory with Flotation "Trepça" in Mitrovica.
\end{abstract}

Qualitative assessment consisted of analyzing the most important indicators and comparing them with drinking water standards according to the Standards of Direc. 98/83 EC, WHOs. From the laboratory data it turns out that the water that emanates from these villages is polluted water as a result of high levels of physico-chemical and microbiological parameters, where in some villages the main problem is the presence of bacteria and metals. The source in the well near the elementary school in Stantërg village according to analyzes and the results obtained results as drinking water.

Keywords- mines, groundwater, physico-chemical, bacteriological and metals indicators.

\section{INTRUDUCTION}

Water, soil and air pollution in many parts of the world but also in Kosovo is a serious environmental problem and a permanent threat to public health, so environmental pollution is a large-scale problem that does not have a national border. [1- 4]

In this paper is presented the bacteriological and physicochemical evaluation as well the determination of the heavy metals of public and domestic wells of some villages in the region of Shala. With the growth and development of the population, the demand for water of a better quality also increases. Poor quality of water is a threat to both the ecosystem itself and the health of people. This is a particularly serious problem and shows a great deal of interest for solutions especially for countries like Mitrovica known as industrial sites, where environmental management practices do not provide for adaptation to economic and 
health development. The quality of water for public use is specified through physical, chemical and microbiological parameters. [5-7]

The main parameters required for drinking water can be divided into these groups:

- organo-leptic parameters,

- physical-chemical parameters,

- undesirable substances,

- bacteriological parameters and

- toxic substances.

This paper presents the mining and metallurgical activity in Trepç, hotspots from mining activities, the spread of natural water and the whole water monitoring process in some villages in the region of Shala. Water monitoring has been conducted at the National Institute of Public Health in Mitrovica, while the determination of the metals has been done at the Mining Laboratory with the Flotation "Trepça" in Mitrovica.

Industrial development that does not respect environmental standards in most cases is the main source of pollution. Through the development of various industrial activities comes the discharge of various waste during water processes such as: heavy metals, various solvents, toxic sludges and many waste of various natures .[8-9]

Kosovo has limited water resources either of surface waters or of groundwater, so their rational protection and use is vital for a sustainable economic development of the country. Most of Kosovo's rivers are seasonal rivers that mostly depend on atmospheric precipitation. Village waters in the Shala region in Mitrovica's hydrographic network represent a country's wealth, but the quality of these waters is not satisfactory.

Groundwaters are sources that lie beneath the surface of the earth, and most of them come from the rains and melting of the ice that fills the spaces between the stones and the soil forming the aquifer and which can be considered as the hidden sources of water. underground are called all the waters that occurred beneath the Earth's surface, in the pits, crevices and other voids of the rocks. They are very widespread and stretch not only in areas with damp climate but also in the dry steppes desert. In the underground is approximately 37 times more water than in all water basins (lakes, swamps, rivers).

The Groundwater Monitoring Program is based on longterm sustainable management of water quality and quantity, which in the future will serve to determine the good ecological status. Systematic water quality monitoring, compliance with local laws in accordance with DKU 2000/60 EC and EU Directives [10-11] To keep the water environment in an industrial region relatively healthy, it should be kept under monitoring by monitoring.

Based on DKU 2000/60 EC and Guidelines no. 16, the protection of water areas used for drinking has affected these steps:

- identification of groundwater bodies (TUN)

- $\quad$ assessment of impacts from human activities

- monitoring

- data analysis

- characterization and division.

The great increase in the use of water for the needs of the population (beverage and personal hygiene), irrigation, industry and other needs has caused two major problems for mankind: lack of water and high pollution. In order to determine the level of pollution, it is necessary to carry out pollution inventory. The designation of a "emission inventory" is to collect and analyze methodologically detailed information on pollutant emissions in certain areas according to local laws and EU standards. [12-14] This inventory contains information on the types of resources and their contribution to pollution.

\section{METHODS AND MATERIALS}

The paper focuses on physico-chemical, bacteriological analysis and determination of metals in groundwater in some villages in the region of Shala. For research, a number of water samples were collected in 6 villages, where 12 samples were collected for research, 6 samples at the beginning of August and 6 samples at the end of August for 6 villages in the region of Shala (in: Zhazhë, Maxherë, Boletin , Stantërg, Zjaqë and Vllahi) from 1L of each sample. The samples were subjected to physico-chemical, bacteriological and metal-based analysis.

Physico-chemical and bacteriological analyzes were carried out at the National Institute of Public Health in Mitrovica, while the determination of the metals was done in the Minier Laboratory with "Flotation" Trepça in Mitrovica.

The general methods for water analysis used are:

- Water sampling and conservation;

- Analytical methods of parameter setting and working methodology;

- Titrimetric and colorimetric methods of analysis;

- $\quad$ photometric and spectrophotometric methods;

- Atomic absorption spectrophotometry (SAA) method;

One of the most important activities during monitoring of well water is sampling and analyzing them. The water monitoring results are dependent on the manner of sampling. 
The sampling method is important just as much as the analysis, so it is important to ensure that samples are not contaminated during taking and transport to the lab so:

The first step - taking 6 samples in the water wells in the villages around the Trepça mine (Zhazhë, Maxherë, Boletin, Stantërg, Zjaqë and Vllahi) from 1L where the water is collected in clean bottles which, before filling, are cleansed two or three times of the same water to be analyzed.
Step Two - After sampling, the vial closes with a tap, where the sampling point, date, time, water temperature and air are recorded.

Third step - Sampling of samples in the laboratory for the determination of physico-chemical, bacteriological and metal determination.

Samples for research were taken twice, 6 samples in early August and 6 samples at the end of August.

The following table presents sampling procedures for sampling how water monitoring is carried out:

Table 1: Sample analysis procedure.

\begin{tabular}{|c|c|c|c|}
\hline Analyte & Type of container & Method of conservation & Storage time \\
\hline Soluble Metals & Plastic, Glass & Field filtration $+\mathrm{HNO}_{3}$ unitil $\mathrm{pH}=2$ & 6 month \\
\hline Metals (total) & Plastic, Glass & Acidification in $\mathrm{pH}=2$ with $\mathrm{HNO}_{3}$ & 6 month \\
\hline $\mathrm{Cr}(\mathrm{VI})$ & Plastic, Glass & Cooling in $4{ }^{0} \mathrm{C}$ & 24 clock \\
\hline $\mathrm{Hg}$ & Q & Acidification in $\mathrm{pH}=2$ with $\mathrm{HNO}_{3}$ & 28 day \\
\hline \multicolumn{4}{|l|}{ Inorganic anion } \\
\hline $\mathrm{Br}, \mathrm{Cl}, \mathrm{F}$ & Plastic, Glass & & 28 day \\
\hline $\mathrm{Cl}_{2}$ & Plastic, Glass & & Immediately \\
\hline Aroma & & & In place \\
\hline $\mathbf{J}$ & Plastic, Glass & Cooling in $4{ }^{0} \mathrm{C}$ & 24 clock \\
\hline $\mathrm{NO}_{3}, \mathrm{NO}_{2}$ & Plastic, Glass & Cooling in $4{ }^{\circ} \mathrm{C}$ & 48 clock \\
\hline $\mathrm{S}$ & Plastic, Glass & $\begin{array}{l}\text { Cooling in } 4{ }^{0} \mathrm{C}+\text { acetate zinc }+\mathrm{NaOH} \text { until } \\
\qquad \mathrm{pH}=9\end{array}$ & 7 day \\
\hline \multicolumn{4}{|l|}{ Organic Substances } \\
\hline $\mathrm{C}$ & $\begin{array}{c}\text { Plastic } \\
\text { Dark Glas s }\end{array}$ & $\begin{array}{r}\text { Cooling in } 4{ }^{0} \mathrm{C}+\mathrm{H}_{2} \mathrm{SO}_{4} \\
\qquad \mathrm{pH}=2\end{array}$ & 28 day \\
\hline $\begin{array}{l}\text { Halogenated } \\
\text { compositions }\end{array}$ & Glass & Cooling in $4{ }^{0} \mathrm{C}+\mathrm{Na}_{2} \mathrm{~S}_{2} \mathrm{O}_{3}(0,008 \%)$ & 14 day \\
\hline \multicolumn{4}{|l|}{ volatile } \\
\hline Aromatic compounds & Glas s & $\begin{array}{c}\text { Cooling in } 4^{0} \mathrm{C}+\mathrm{Na}_{2} \mathrm{~S}_{2} \mathrm{O}_{3}(0,008 \%)+\mathrm{HCl} \\
\text { until pH=2 }\end{array}$ & 14 day \\
\hline PCB & Glass ,Teflon & Cooling in $4{ }^{0} \mathrm{C}$ & 7 day \\
\hline Temperature & & & In place \\
\hline $\mathrm{pH}-\mathrm{ja}$ & & & In place \\
\hline BOD & Plastic, Glass & Cooling in $4{ }^{\circ} \mathrm{C}$ & 48 clock \\
\hline COD & Plastic, Glass & Cooling in $4{ }^{0} \mathrm{C}$ & 48 clock \\
\hline
\end{tabular}

During the experimental work we used these devices:

- Conductometer

- Turbidimeter

- photometry

- $\mathrm{pH}$ meter \& thermometer

- Technical scales

- Horizontal stirrer

- Incense burner, 1100 OC 
- Analytical scales

- Absorber Atomic, Model - Thermo

Sampling sites for the determination of metals in public wells in some villages around the mine "Trepça" are: (Zhazhë, Maxherë, Boletin, Stantërg, Zjaqë and Vllahi).

Sampling (in 6 villages) of $250 \mathrm{ml}$. Filter the samples and place them in 6 wells with $100 \mathrm{ml}$ of distilled water from each sample for the continuation of the process whereby each sample is supplemented with $1 \mathrm{~mL} \mathrm{HNO3}(65 \%)$.

Table 2: Types of reagents and their description

\begin{tabular}{|l|c|c|}
\hline Naming : & Formula: & Description : \\
\hline Hydrochlorid acid & $\mathrm{HCl}$ & Tincture , 1:4 \\
\hline Hydroxide of sodium & $\mathrm{NaOH}$ & (molariteti) \\
\hline Hidroxide of calium & $\mathrm{KOH}$ & (molariteti) \\
\hline Nitric acids & $\mathrm{HNO}_{3}$ & $1 \%$ \\
\hline Amidon & $\mathrm{C}_{6} \mathrm{H}_{10} \mathrm{O}_{5}$ & $2 \%$ \\
\hline Fenoftalein & $\mathrm{C}_{20} \mathrm{H}_{14} \mathrm{O}_{4}$ & $20-100 \mathrm{Ml}$ \\
\hline Destilled water & $\mathrm{H}_{2} \mathrm{O}$ & Tincture , 1:3 \\
\hline Sulfuric acids & $\mathrm{H}_{2} \mathrm{SO}_{4}$ & 0.01 (molariteti) \\
\hline Potassium Permanganate & $\mathrm{KMnO}_{4}$ & $25 \%$ \\
\hline Potassium chromium & $\mathrm{K}_{2} \mathrm{CrO}_{4}$ & 0.01 (molariteti) \\
\hline Ammonium hydroxide & $\mathrm{NH}_{4} \mathrm{OH}_{2}$ & Tincture \\
\hline Thiosulfate sodium & $\mathrm{Na}_{2} \mathrm{~S}_{2} \mathrm{SO}_{3}$ & \\
\hline Puffer digestion & $\mathrm{NH}_{4} \mathrm{Cl}_{+} \mathrm{NH}_{4} \mathrm{OH}$ & 0.05 (molariteti) \\
\hline Silver nitrate & $\mathrm{AgNO}_{3}$ & 0.05 (molariteti) \\
\hline Oxalic acids & $\mathrm{C}_{2} \mathrm{H}_{2} \mathrm{O}_{4}$ & \\
\hline Kompleksion III & & $\mathrm{BaCrO}_{4}$ \\
\hline Barium chromates & & \\
\hline
\end{tabular}

The laboratory work tools needed to develop the experimental part: Protective equipment (mantillas, handkerchiefs, glasses), Erlenmajer (300 ml), Menzur (100 $\mathrm{ml})$, Automatic Bureta $(50 \mathrm{ml})$, Pipette, Cup Porcelain, Hinka Separate, Quantitative Filter Paper, Chemical Spoons, Metallic Caps, plastic. Samplers and sampling tools should be cleaned each time with distilled water after use. The samples are placed in the digesters at a temperature of $(100-160){ }^{\circ} \mathrm{C}$ and last for $(18-20) \mathrm{min}$, then cooled to room temperature, $(30-40)^{\circ} \mathrm{C}$, placed in normal container through the husk and leveled with distilled water (up to the line).

After leveling, the samples are ready for inputting at the Atomic Absorber, initially adjust the processes in the program (PC) for 5 elements: $\mathrm{Pb}, \mathrm{Zn}, \mathrm{Cu}, \mathrm{Cd}$ and $\mathrm{Fe}$.

\section{DISCUSSION OF RESULTS}

Water quality in villages in the Shala region is influenced by natural factors and by anthropogenic activities in the area around water wells. The water quality is estimated for the villages: Zhazhë, Maxherë, Boletin, Stantërg, Zjaqë and Vllahi in the beginning of August and end of August, 2018. Comparisons of physical-chemical and bacteriological parameters were made with the standards allowed under Direc. 98/83 EC, while monitoring of villages in the region of Shala were made comparisons of metal results with MSHK.

Based on the working methods, the results of the analyzed samples are presented in tabular form and figure.

Tables are divided according to the number of physicalchemical analyzes at the beginning of August and at the end of August. 
Table 3: Results of physical-chemical analysis at the beginning of August.

\begin{tabular}{|c|c|c|c|c|c|c|c|c|}
\hline $\begin{array}{l}\text { 04.08.2018 } \\
\text { Settings: }\end{array}$ & Units: & 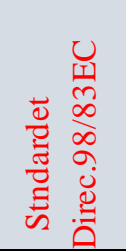 & 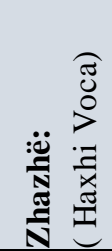 & 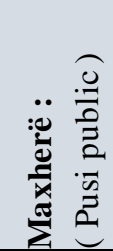 & 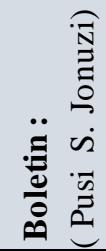 & 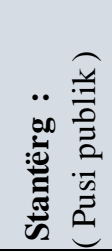 & 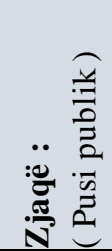 & 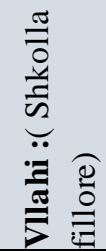 \\
\hline Temperature & ${ }^{0} \mathrm{C} / \mathrm{K}$ & $8-12$ & 15 & 17.1 & 12 & 15.2 & 13 & 16.9 \\
\hline Wind & & $\mathrm{Pa}$ & $\mathrm{Pa}$ & $\mathrm{Pa}$ & $\mathrm{Pa}$ & $\mathrm{Pa}$ & $\mathrm{Pa}$ & $\mathrm{Pa}$ \\
\hline Taste & & $\mathrm{Pa}$ & $\mathrm{Pa}$ & $\mathrm{Pa}$ & $\mathrm{Pa}$ & $\mathrm{Pa}$ & $\mathrm{Pa}$ & $\mathrm{Pa}$ \\
\hline Turbidity & NTU & $1.2-2.4$ & 0.00 & 0.00 & 0.64 & 0.00 & 0.00 & 0.82 \\
\hline Color & Co-Pt & $10 .-20.0$ & $\mathrm{~Pa}$ & $\mathrm{~Pa}$ & $\mathrm{~Pa}$ & $\mathrm{~Pa}$ & $\mathrm{~Pa}$ & $\mathrm{~Pa}$ \\
\hline The value of $\mathrm{pH}$-së & $\mathrm{pH}$ & $6.8-8.5$ & 7.0 & 7.87 & 7.2 & 7.93 & 7.6 & 7.98 \\
\hline Spending $\mathrm{KMnO}_{4}$ & $\mathrm{mg} / \mathrm{L} \mathrm{O} \mathrm{O}_{2}$ & $8-12$ & 7.48 & 5.72 & 4.36 & 2.70 & 3.36 & 6.08 \\
\hline Free Chlorine & $\mathrm{mg} / \mathrm{L} \mathrm{Cl}_{2}$ & $0.2-0.5$ & 0.00 & 0.00 & 0.00 & 0.00 & 0.00 & 0.00 \\
\hline Clorides & $\mathrm{mg} / \mathrm{L} \mathrm{Cl}$ & 200 & 27 & 17 & 92.5 & 25 & 43 & 17 \\
\hline Ammonia & $\mathrm{mg} / \mathrm{L} \mathrm{N}$ & 0.1 & 0.02 & 0.01 & 0.01 & 0.04 & 0.00 & 0.02 \\
\hline Nitritets & $\mathrm{mg} / \mathrm{L} \mathrm{N}$ & 0.005 & 0.007 & 0.005 & 0.008 & 0.006 & 0.014 & 0.007 \\
\hline Nitratets & $\mathrm{mg} / \mathrm{L} \mathrm{N}$ & 10 & 0.3 & 0.6 & 1.5 & 4.8 & 0.9 & 0.7 \\
\hline Elektricity quarrel & $\mathrm{ms} / \mathrm{cm}$ & 1500 & 450 & 706 & 692 & 506 & 779 & 306 \\
\hline Sulfates & $\mathrm{mg} / \mathrm{L} \mathrm{SO}_{4}^{-2}$ & 200 & 13.44 & 25.02 & 30.14 & 36.86 & 26.62 & 36.86 \\
\hline Total hardness & ${ }^{0} \mathrm{dH}$ & 30 & 13.44 & 23.632 & 18.32 & 11.2 & 11.42 & 7.56 \\
\hline
\end{tabular}

Table 4: Results of physical-chemical analysis at the end of August.

\begin{tabular}{|c|c|c|c|c|c|c|c|c|}
\hline $\begin{array}{l}24.08 .2018 \\
\text { Settings: }\end{array}$ & Units: & 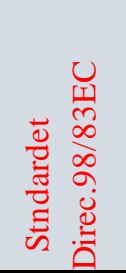 & 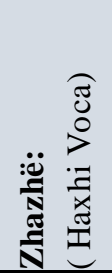 & 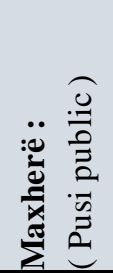 & 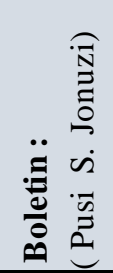 & 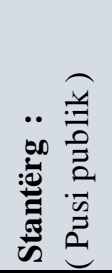 & 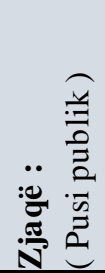 & 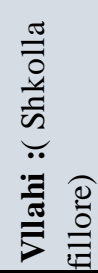 \\
\hline Temperature & ${ }^{0} \mathrm{C} / \mathrm{K}$ & $8-12$ & 15 & 21.6 & 9 & 22.8 & 13 & 21.9 \\
\hline Wind & & $\mathrm{Pa}$ & $\mathrm{Pa}$ & $\mathrm{Pa}$ & $\mathrm{Pa}$ & $\mathrm{Pa}$ & $\mathrm{Pa}$ & $\mathrm{Pa}$ \\
\hline Taste & & $\mathrm{Pa}$ & $\mathrm{Pa}$ & $\mathrm{Pa}$ & $\mathrm{Pa}$ & $\mathrm{Pa}$ & $\mathrm{Pa}$ & $\mathrm{Pa}$ \\
\hline Turbidity & NTU & $1.2-2.4$ & 0.00 & 0.00 & 0.40 & 0.00 & 38.13 & 0.00 \\
\hline Color & $\mathrm{Co}-\mathrm{Pt}$ & $10 .-20.0$ & $\mathrm{~Pa}$ & $\mathrm{~Pa}$ & $\mathrm{~Pa}$ & $\mathrm{~Pa}$ & $\mathrm{~Pa}$ & $\mathrm{~Pa}$ \\
\hline The value of $\mathrm{pH}$-së & $\mathrm{pH}$ & $6.8-8.5$ & 7.7 & 7.81 & 7.11 & 6.83 & 7.9 & 7.61 \\
\hline Spending $\mathrm{KMnO}_{4}$ & $\mathrm{mg} / \mathrm{L} \mathrm{O} \mathrm{O}_{2}$ & $8-12$ & 8.47 & 6.08 & 9.0 & 6.44 & 12.23 & 5.72 \\
\hline Free Chlorine & $\mathrm{mg} / \mathrm{L} \mathrm{Cl} 2$ & $0.2-0.5$ & 0.00 & 0.00 & 0.00 & 0.00 & 0.00 & 0.00 \\
\hline Clorides & $\mathrm{mg} / \mathrm{L} \mathrm{Cl}$ & 200 & 20 & 15 & 26 & 46 & 16 & 18 \\
\hline Ammonia & $\mathrm{mg} / \mathrm{L} \mathrm{N}$ & 0.1 & 0.01 & 0.03 & 0.01 & 0.03 & 0.18 & 0.02 \\
\hline Nitritets & $\mathrm{mg} / \mathrm{L} \mathrm{N}$ & 0.005 & 0.005 & 0.006 & 0.010 & 0.004 & 0.089 & 0.006 \\
\hline Nitratets & $\mathrm{mg} / \mathrm{L} \mathrm{N}$ & 10 & 2.4 & 1.2 & 2.6 & 8.6 & 1.3 & 1.9 \\
\hline Elektricity quarrel & $\mathrm{ms} / \mathrm{cm}$ & 1500 & 272 & 440 & 617 & 773 & 414 & 427 \\
\hline Sulfates & $\mathrm{mg} / \mathrm{L} \mathrm{SO}_{4}{ }^{-2}$ & 200 & 5.18 & 31.1 & 22.14 & 102.78 & 10.62 & 53.18 \\
\hline Total hardness & 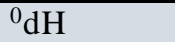 & 30 & 5.6 & 6.872 & 14.56 & 14.672 & 5.71 & 8.176 \\
\hline
\end{tabular}


Table 5: Results of determination of metals during August.

\begin{tabular}{|c|c|c|c|c|c|c|c|}
\hline $\begin{array}{l}\text { 24. 08. } 2018 \\
\text { Type of Metal }\end{array}$ & 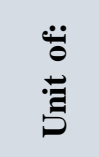 & $\begin{array}{l}: 0 \\
: \stackrel{\Xi}{N} \\
\frac{\mathbb{N}}{N}\end{array}$ & 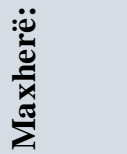 & 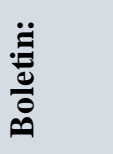 & 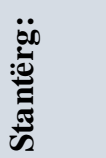 & $\ddot{\ddot{\vec{\sigma}}}$ & $\frac{\ddot{\vec{E}}}{\stackrel{\vec{J}}{\bar{J}}}$ \\
\hline $\mathbf{P b}$ & $\mathrm{mg} / \mathrm{L}$ & 0.100 & 0.099 & 0.223 & 0.037 & 0.016 & 0.093 \\
\hline $\mathbf{Z n}$ & $\mathrm{mg} / \mathrm{L}$ & 0.1509 & 0.1214 & 0.039 & 0.026 & 0.045 & 0.413 \\
\hline $\mathbf{C u}$ & $\mathrm{mg} / \mathrm{L}$ & 0.0025 & $<0.001$ & 0.0989 & $<0.001$ & 0.0021 & 0.006 \\
\hline $\mathrm{Cd}$ & $\mathrm{mg} / \mathrm{L}$ & 0.0022 & $<0.001$ & $<0.001$ & $<0.001$ & $<0.001$ & $<0.001$ \\
\hline $\mathbf{F e}$ & $\mathrm{mg} / \mathrm{L}$ & 2.991 & 4.308 & 0.142 & 0.446 & 1.996 & 0.178 \\
\hline
\end{tabular}

Table 6: Maximum allowable values of metals for drinking water according to different international organizations.

\begin{tabular}{|c|c|c|c|c|c|}
\hline & & MSHK, 16/2012 & OBSH dhe WHO's & EPA (BE) & EU, 2014 \\
\hline $\mathrm{Pb}$ & $\mathrm{mg} / \mathrm{l}$ & 0.01 & 0.01 & 0.05 & 0.01 \\
\hline $\mathrm{Zn}$ & $\mathrm{mg} / \mathrm{l}$ & 0.00 & 3.0 & 3.0 & 0.00 \\
\hline $\mathrm{Cu}$ & $\mathrm{mg} / \mathrm{l}$ & 2.0 & 2.0 & 2.0 & 2.0 \\
\hline $\mathrm{Cd}$ & $\mathrm{mg} / \mathrm{l}$ & 0.005 & 0.001 & 0.005 & 0.005 \\
\hline $\mathrm{Fe}$ & $\mathrm{mg} / \mathrm{l}$ & 0.2 & $0.5-50$ & 0.2 & 0.2 \\
\hline
\end{tabular}

Table 7: Results of bacteriological analysis at the beginning of August.

\begin{tabular}{|l|l|}
\hline Samples : 04.08.2018 & Results : \\
\hline Zhazhë $\quad$ (Home well Haxhi Voca $)$ & Spotted with proteus vulgaris and live bacteria. \\
\hline Maxherë $\quad$ (The village public Well $)$ & Spotted with live bacteria. \\
\hline Boletin $\quad$ ( Home well S. Jonuzi $)$ & Spotted withclostridium, and live bacteria. \\
\hline Stantërg $\quad$ (The village public Well $)$ & Spotted withacinetobactere. \\
\hline Zjaqë ( The village public Well $)$ & Spotted withcitrobactere. \\
\hline Vllahi (Well near school) & Spotted withescherichia coli. \\
\hline
\end{tabular}

Table 8: Results of bacteriological analysis at the end of August.

\begin{tabular}{|l|l|}
\hline Samples : 25. 08.2018 & Results : \\
\hline Zhazhë (Home well Haxhi Voca ) & Spotted withescherichia coli and clostridium. \\
\hline Maxherë ( Pusi publik i fshatit ) & Spotted withescherichia coli and clostridium. \\
\hline Boletin $\quad$ (Home well S. Jonuzi) & Spotted withescherichia coli and live bacteria. \\
\hline Stantërg (The village public Well ) & Unwanted. \\
\hline Zjaqë ( The village public Well ) & Spotted withcitrobactere and clostridium. \\
\hline Vllahi (Well near school) & Spotted withescherichia coli. \\
\hline
\end{tabular}

Temperature: in the villages of Maxherë (17.1 - 21.6) OC, Stantërg (15.2 - 22.8) OC and Vllahi (16.9 - 21.9) OC compared to the standard $(8-12) 0 \mathrm{C}$. These levels vary in changing climatic conditions.

Turbidity: the standard is (1.2-2.4) NTU, there was overpass in the village of Zjaqë (38.13) NTU. These high levels of turbidity are observed after rainfall but also as a result of the influence of the anthropogenic factor
Expenditures of $\mathbf{K M n O}_{4}: 9.0 \mathrm{mg} / \mathrm{L}$ in the village of Boletin up to $12.23 \mathrm{mg} / \mathrm{L}$ in Zjaqë village compared to standard (812) $\mathrm{mg} / \mathrm{L}$. The data show that the quality of treated water is moderately good.

Bacteriological: According to the results of the water analysis in the village of Zhazhë, the water is contaminated with live bacteria. In the village of Maxherë there are live bacteria, in the village of Boletin the water is contaminated 
with living bacteria, Stantërgu the public well of the village is contaminated with acinetobactere while the well near the school is unpolluted, in Zjaqë the water is polluted and in the wells of the Vllahi village the water is dirty. The result of anthropogenic factor influence.

Nitrite: standard is $0.005 \mathrm{mg} / \mathrm{L}$, exceeded in the village of Zhazhë $0.007 \mathrm{mg} / \mathrm{L}$, in Boletin village (0.008-0.010) $\mathrm{mg} / \mathrm{L}$, in Stantërg village $0.006 \mathrm{mg} / \mathrm{L}$, in village Zjaq (0.014$0.089) \mathrm{mg} / \mathrm{L}$ and in the village Vllahi $0.007 \mathrm{mg} / \mathrm{L}$. The result of anthropogenic factor influence.

Metals: $\mathrm{Pb}$ standard is $0.01 \mathrm{mg} / \mathrm{L}$, Zhazhë has exceeded $0.100 \mathrm{mg} / \mathrm{L}$, in Boletin exceeds $\mathrm{Pb} 0.223 \mathrm{mg} / \mathrm{L}$, and in Vllahi village it exceeds the $\mathrm{Pb}$ standard where $\mathrm{Pb}$ values are $0.093 \mathrm{mg} / \mathrm{L}$. The iron has exceeded in Stantërg 0.446 $\mathrm{mg} / \mathrm{L}$ limit, in Zijaqë $1.996 \mathrm{mg} / \mathrm{L}$, in Zhazhë $2.991 \mathrm{mg} / \mathrm{L}$ and Maxherë $4.308 \mathrm{mg} / \mathrm{L}$ compared to the standard of 0.2 $\mathrm{mg} / \mathrm{L}$. These exceedance of standards is a result of the Earth's natural composition.

\section{CONCLUSIONS AND RECOMMENDATIONS}

From the above, we conclude that the human factor with its activity is endangering life on the ground and every day and more is degrading the nature of man that is causing man economic loss and difficulty in life. Water care means taking care of life on earth so water care means life-time care, so environmental engineers and specialists of this field are confirming the big changes in drinking water from anthropogenic emissions. These changes are in the growth of the polluting elements in the water and the elements of the pathogenic microorganisms which are coming to various infections, where it is noted that the care of the citizens and the maintenance of the environment are almost completely missing in those locations in the region of Shala where these main conclusions were reached:

- The greatest exploitation of these resources occurred during the 70's and 80's and as a consequence, many problems have also been inherited in the field of environment.

- The biggest environmental problem from this mining is polluted mine water that is polluting the area around the mine as a result of land flow and penetration into groundwater.

- The qualitative assessment of groundwater in the villages around the mine "Trepça" consisted in analyzing the most important indicators and their comparison with drinking water standards according to Standards, IA 2/99 (UNMIK).
From the laboratory data it turns out that the water that emanates from these villages is polluted water since the levels of the physico-chemical and microbiological parameters are high, besides the well near the elementary school in the village of Stantërg according to the analysis resulted as drinking water.

Based on the field survey and the results of the physicochemical, bacteriological analysis and determination of heavy metals from the analyzed samples, we conclude that the following recommendations would be for the preservation of water quality and environmental protection of particular importance:

- Maintain the quality of drinking water from pesticides, waste and agricultural crops.

- Handle sewage and control their discharge into surface waters.

- Setting up information tables for water resource conservation.

- Monitoring the spaces declared as protected areas by the law in force by MESP.

- Approval of laws and regulations for water users in harmony with the EU.

- Protection and preservation of water resources and their use in sustainable development principles.

\section{REFERENCES}

[1] Hoxha, B. (1999):Analytical chemistry-the practical part, Prishtinë;

[2] Dalmacija B. (2000): Kontrolla kvaliteta voda, Novi Sad;

[3] Korça, B. (2001): Water Chemical Analysis, Prishtinë;

[4] Davis, M.L., Masten, S.,(2004) Principles of Enivromental Engineering and Sciece, Mc Graw Hill, USA;

[5] Lal,R., (2006) Enciclopedia of soil Science, CRC Press, USA.

[6] WHO (2006): Guidelines for Drinking Water Quality, First Addendum to the Third Edition, Volume 1;

[7] Kosovo Environmental Action Plan (2006-2010), MMPH/REC, 2006;

[8] Report on the state of the environment(2006/2007) AMMK 2008, Prishtinë;

[9] Progress Monitoring Report, REC, (2008), Prishtinë.

[10] Cullaj, A. (2010):Environmental Chemistry,Tiranë;

[11] Environmental Hotspots in Kosovo, (2011) raport nga AMMK 
[12] Shallari S. (2013): Assessment and Environmental Management, Tiranë;

[13] Report on the state of water in the Republic of Kosovo by the Ministry of Environment and Spatial Planning.

[14] The program for heritage revival and rural development, Stantërg, Mitrovicë. 